\title{
Korona Günlerinde Gazetecilik: İzmir'de Haber Takibi
}

\author{
A. Buğra Kalender (Öğr. Gör.) \\ İzmir Kavram Meslek Yüksekokulu \\ bugra.kalender@kavram.edu.tr \\ Mete Kazaz (Doç. Dr.) \\ iD Selçuk Üniversitesi Iletiş̧im Fakültesi \\ mkazaz@selcuk.edu.tr \\ Başvuru Tarihi: 31.07.2021 \\ Yayına Kabul Tarihi: 18.10 .2021 \\ Yayınlanma Tarihi: 28.10.2021 \\ https://doi.org/10.17680/erciyesiletisim.977009
}

\section{Öz}

İlk olarak Çin'in Wuhan bölgesinde ortaya çıktığı düşünülen ve kısa süre içerisinde tüm dünyaya yayılarak pandemiye sebep olan Koronavirüs (COVID-19), Türkiye'de de etkisini ciddi bir şekilde göstermiştir. Pandemi gibi kriz süreçleri önemli derecede haber değerine sahiptir. Genel olarak kriz süreçlerinin tamamında toplumun en önemli enformasyon kaynağı haber medyasıdır. Gazeteciler de bu süreçte pek çok farklı deneyimler yaşar ve haber üretimi çoğu zaman daha zorlu bir hale gelir. Bu çalışmanın konusunu, koronavirüs pandemisi ve kriz haberciliği bağlamında gazetecilik mesleğindeki pratikleri ele almak oluşturmaktadır. Çalışmanın amacı ise, koronavirüs pandemisi süresince gazetecilerin çalışma koşullarındaki değişimlerin ortaya çıkartılması ve gazetecilerin konu hakkındaki görüşlerinin aktarılmasıdır. Nitel araştırma yönteminin tercih edildiği çalışma fenomenolojik desene uygun olarak inşa edilmiştir. Araştırma İzmir'deki gazeteciler ile yapılmış ve veri toplamak için derinlemesine görüşme tekniği kullanılmıștır. Çalışma sonucunda, pandemi sürecinde gazetecilik bağlamında ortaya çıkan değişimler temalar halinde sunulmuş ve gazetecilerin bu süreçte yaşadığı deneyimlerin haber takibini daha zorlu hale getirdiği bulgulanmıştır.

Anahtar Kelimeler: İletişim, Gazetecilik, Haber, Koronavirüs, COVID-19. 


\title{
Journalism in the Days of Corona: News Tracking in İzmir
}

\section{A. Buğra Kalender (Lect.)}

İzmir Kavram Vocational School bugra.kalender@kavram.edu.tr

Mete Kazaz (Assoc. Prof. Dr.)

iD Selçuk University Faculty of Communication mkazaz@selcuk.edu.tr

Date Received: 31.07.2021

Date Accepted: 18.10 .2021

Date Published: 28.10.2021

https://doi.org/10.17680/erciyesiletisim.977009

\begin{abstract}
Firstly thought to occur in Wuhan, China and soon Coronavirus (COVID-19) that causes pandemic spread around the world, it also showed a serious impact in Turkey. Crisis processes such as pandemics have significant news value. The most important information source of the society in all crisis processes is the news media. Journalists have many different experiences in this process, and news production often becomes more challenge. The subject of this study is to deal with the practices in the journalism profession in the context of the coronavirus pandemic and crisis jorunalism. The aim of the study is to reveal the changes in the working conditions of journalists during the coronavirus pandemic and to convey the journalists views on the subject. The study in which the qualitative research method was preferred, was constructed in accordance with the phenomenological pattern. The research was conducted with journalists in Izmir and in-depth interview technique was used to gather data.
\end{abstract}

Keywords: Communication, Journalism, News, Coronavirus, COVID-19. 


\section{Giriş}

Haber, her zaman için dikkat gerektiren bir fikirsel üretimdir. Ancak kriz durumlarında rutin zamanlara oranla daha çok dikkat gerektirmektedir. Toplumun bilgi edinme ihtiyacı çerçevesinde en büyük dilimi kapsayan medya, kriz dönemlerinde en önemli bilgi kaynağı haline gelmektedir.

Kriz haberciliği, belirli olaylarla ilgili olarak uzun yıllara yayılan bir süreçte araștırmalara konu olmuştur. Özellikle terör saldırıları ve diğer olağanüstü durumlar, doğrudan ya da dolaylı bir şekilde kriz haberciliğinin odağı haline gelmiştir (Olsson \& Nord, 2015). Meslek etiği açısından her zaman topluma karşı büyük bir sorumluluğu olan gazetecilerin özellikle kriz dönemlerinde bu sorumluluğu daha da artmaktadır. Kamuoyundaki yaygın merak ve endișenin giderilmesi, doğruluğu teyit edilmiş bilgilerin insanlara sunulması gazeteciler için bu süreçte çok daha elzemdir.

Salgın süreçleri en başta büyük bir sağlık krizidir. Ancak ortaya koyduğu etkiler sadece sağlık ile sınırlı değil psikolojik, sosyolojik ve ekonomik olmak üzere çok boyutlu bir kırılmayı tetiklemektedir. İnsanlar bu süreçte neler olup bittiğini öğrenmek ve karşılaşabilecekleri risklere karşı önlem almak için ihtiyaç duydukları bilgileri daha çok medyadan öğrenmektedirler (Spence, Westerman, Skalski, Seeger, Sellnow \& Ulmer, 2006; Lyu, 2012). Koronavirüs salgını insanların doğru ve güvenilir bilgi arayıșını arttırmış ayrıca gazeteciliğin sosyal ve kültürel açıdan önemini bir kez daha göstermiştir (Luengo \& Garcia-Marin, 2020). Gazetecilik, özellikle kriz zamanlarında ulusal etkilere eğilir ve pandemi her ne kadar büyük ölçekli olsa da ülkenin mevcut koşulları ve durumu yayıncılığın ana gündemine oturmaktadır (Kunelius, 2020, s.3).

Koronavirüs pandemisi bilimsel literatürde sadece fen ve sağlık alanında değil, toplumda yarattığı etki dolayısıyla ciddi oranda sosyal bilimlerin konusu haline gelmiştir. Özel olarak pandemi ve medya bağlamında düşünüldüğünde yapılan çalışmaların genellikle medya metinleri ve haberlerin toplum üzerine bıraktığı etkiler ile haberde söylem ve sunuş biçimlerine yönelik yapıldığı görülmektedir. Koronavirüs, dünya çapındaki toplumları ve gazeteciliği hazırlıksız yakalamıştır. Bu yüzden sadece kişilerin sağlı̆̆ı üzerinde değil aynı zamanda toplumda da benzersiz etkilere neden olmuştur (Quandt, Boberg, SchattoEckrodt, T., \& Frischlich, 2020, s.3). Ancak pek çok sektörde çalışma hayatını etkileyen ve belli başlı değişikliklere gidilmesine neden olan pandeminin gazetecilerin çalışma koşulları üzerindeki etkilerine dair bir çalışma mevcut değildir.

$\mathrm{Bu}$ noktadan hareketle bu çalışmanın literatür kısmında ilk olarak kriz haberciliği kavramına değinilmiş, kriz sürecinde yapılan habercilik faaliyetinin içeriği ve gerekliliği üzerinde durulmuştur. Ardından bir kriz örneği olarak koronavirüs sürecine bakılmış ve bu süreçte haber medyasının durumu ele alınarak konuyla ilgili literatür taranmıștır. Söz konusu literatürün haber medyasındaki yayınların içerikleri üzerinde yapılan çalışmalar olduğu gözlemlenmiş ve gazetecilerin süreçteki deneyimleri üzerine bir çalışmanın eksikliği göze çarpmıştır. Bundan kaynaklı olarak çalışmanın metodoloji kısmında kriz haberciliğinin pratik bir örneği olan koronavirüs süreci işlenmiş, gazetecilerin koronavirüs krizini nasıl deneyimlediklerine ve bu süreçte mesleğin yapılış biçimdeki değişenlerin/ değişmeyenlerin neler olduğunu saptamaya odaklanılmıștır. Araştırma Türkiye'nin nüfus bakımında en kalabalık 3. şehri olan İzmir'de yapılmıştır. Araştırmanın katılımcı grubu ise koronavirüs sürecinin öncesinde aktif olarak gazetecilik yapmaya başlayan ve halen daha devam eden gazetecilerden oluşturulmuştur. Çalışmada derinlemesine görüşmeler yapılarak veriler toplanmış, oluşan veri seti üzerinde betimsel analiz uygulanmıştır. 


\section{Kriz Haberciliği}

İngilizce "crisis" sözcüğünden Türkçe'ye 'kriz' olarak geçen kavramla ilgili farklı kaynaklarda bilgiler mevcuttur. Ancak sözcügün etimolojik yolculuğuna bakıldığında ilk olarak Antik Yunan'da kullanıldığı bilgisine ulaşılmaktadır. Eski Yunancadaki "krisis" ve "krinein" sözcüklerinden türediği öne sürülen kelimenin zaman içerisinde kullanım amacı değişmiștir. Eski Yunancada "karar vermek" anlamına gelen 'krinein' sözcügünün tıp literatüründe de kullanılmasıyla bu sözcük daha çok yaygınlık kazanmıştır. Tıp alanındaki kullanım maksadı, hastalık sürecinde akut dönemini ve hastalık belirtilerinin daha çok yaygınlaşmaya başladığı gibi durumları ifade etmek içindir (Hatemi, 1999, s. 17). Buradaki kriz, hastalığın seyrindeki önemli anı ya da kritik eşiği belirtmek amacıyla kullanılmaktadır (Çınarlı, 2016, s. 25). Kriz sözcüğünün günümüzdeki karşılı̆̆ı ise daha kapsayıcı bir anlam taşıyarak "birçok insanı etkileyen, sıkıntıya, güçlüğe ve ölüme neden olabilen ciddi ve tehlikeli bir durum" şeklinde belirtilmektedir (Filiz, 2007; Güneş ve Beyazit, 2010).

Kriz kavramı genel olarak, beklenmedik bir şekilde ve ani olarak gelişen ve toplumsal düzende ciddi aksamalara neden olan olay ya da olaylar için kullanılmaktadır. Doğal afet, kaza, terör saldırısı, salgın hastalık, ekonomik ve siyasal bunalım gibi durumların tek başına ya da birbirini tetikleyerek yaşanması durumunda daha da belirginlik kazanmaktadır. Gazetecilik faaliyeti açısından bakıldığında ise toplumu ilgilendiren her kriz anı, öncesi ve sonrası da dâhil olmak üzere ciddi bir haber değeri taşımaktadır.

Konuya gazetecilik pratiği ve haber değeri açısından bakıldığında, kriz durumlarında her zaman güçlü bir haber değeri bulunmaktadır. Kriz haberciliği; politik, ekonomik ya da sosyal alanlarda ani bir şekilde meydana gelen ve tehlikeli bir süreci işaret edebilecek habercilik türü olarak ifade edilmektedir (Yüksel, 2010, s. 280). Ulusal ve uluslararası politikadaki yaşanan krizler (savaş, terör saldırısı, diplomatik gerginlik vd.) yoğun bir haber gündemi yaratmaktadır. Bununla birlikte doğal afetler (sel, deprem, kasırga, heyelan, tsunami vd.) sonucunda yaşanan mağduriyetler ve kayılar yine bu kriz sürecindeki en bilinen haber öyküleri arasında gelmektedir. Ayrıca dönem dönem ortaya çıkan salgın hastalıkların (domuz gribi, MERS, Ebola, Zika virüsü, COVID-19 vd.) yayılma sürecinde yaşananlar haber değeri açısından oldukça önemlidir.

Bahsedilen bu farklı kriz durumları karşısında haber medyası da belirli rutinler ve pratikler geliştirmiştir (Nord \& Strömbäck, 2006; Usher, 2009; Olsson \& Nord, 2015). Durham’a (2008) göre kriz sürecine dair öncesinden yapılan hazırlıklar ve prosedürler, süreçle başa çıkmada önemli ölçüde yardımcı olmaktadır. Bu hazırlıklı olma durumu esasında gazeteciliğin doğası gereği her zaman mevcut olsa da normal sürecin dışında gelişen olaylar bazen mesleğin yapılışını etkilemektedir. Riegert and Olsson'a (2007) göre ise kriz haberciliğin en önemi işlevi devlet ve yurttaşlar arasındaki iletişimin sağlanmasıdır. Meydana gelen kaza, saldırı, felaket, salgın vb. kriz süreci kitleler tarafından takip edilmekte ve devlet görevlileri de medya aracılığıyla kamuoyunu bilgilendirme sorumluluğunu yerine getirmektedir. Jarlbro (2004) da kriz haberciliği üzerine yaptığı çalışmada, bilim insanlarının bu haberlere konu olan olayların nedenlerini ve içeriğini raporladığını, ancak bu haberlerin neden farklı șekillerde izleyiciye yansıtıldığı sorusunu sorarak ayrı bir tartışmayı aralamıștır.

Kriz haberciliği, her şeyden önce medyanın kamuoyunu bilgilendirme işlevinden hareketle yapılması gereken bir habercilik türüdür. Ancak yaşanan örnekler kriz haberciliğinin daha çok bu bilgilendirme işlevi ile gerilimli bir şekilde ilerlediğini göstermektedir. Bir yandan 
kriz halinde yaşananları anlayabilmek ve geleceğe ilişkin yordamada bulunabilmek için bilgi ve analize ihtiyaç duyulmakta, diğer yandan ise ticari haber üretimi açısından bu durum bir "fırsat" şeklinde görülmektedir. Haliyle haber medyasının en önemli işlevini yerine getireceği kriz ortamları, aynı zamanda haberin toplumsal işlevinin kesintiye uğratıldığı durumları da içermektedir (Çaplı \& Taş, 2009, s. 238).

Haberin bir çok türünde görülmesine rağmen özellikle kriz haberlerinde sansasyonel söylemler ön plana çıkartılmakta, haber içeriğindeki görüntü ve sesler müzik efektleriyle beraber video tekrarı (replay) yapılarak izleyiciye sunulmaktadır. Çaplı ve Taş'a (2009) göre ise kriz anlarında izleyicinin merakı daha çok kışkırtılır. Özellikle şiddet içerikli görüntüler ekrana yansıtılır ve beraberinde ajitasyon dili kullanılarak hedef kitleye egemen kodlar aşılanır. Terör saldırıları ve salgın hastalıkların yayılması gibi durumlarda toplumda yaşanan korku ve panik, sahte (fake) görüntüler, abartılı rakamlar ve hatalı bilgileri içeren ifadelerle daha da arttırılmaktadır.

Kriz haberlerinde yayınlanan görüntüler bireylerin psikolojisini ciddi oranda etkileyebilmektedir. Bu tarz durumlarda bireylerin korku ve endișe düzeyi yoğun biçimde artış göstermektedir. Bununla beraber yașanan olay hakkında bilgi sahibi olma ve süreçteki belirsizlikleri giderebilmek için kişilerde bilgi edinme isteği artmaktadır. Aynı zamanda okuyucu/izleyici için bir diğer handikap ilk anda alınan bilgilerin eleştirel bir şekilde değerlendirilmesinin güç olduğudur. Bu haliyle kriz dönemlerinde yayınlanan haberlerin kamuoyu tarafından "doğru/gerçek" şeklinde algılanma eğilimi yüksektir (Güngör Firat, 2011, s. 38). Gazete için tiraj, radyo ve televizyon için reyting neyse internet platformu için de tık (click) aynı șeyi ifade etmektedir. Özellikle dijital medyada daha fazla tık almak için tık yemi (clickbait) haberlerin çok fazla yaygınlaştığı görülmektedir (Kalender, 2019, s. 7).

Kriz haberciliğinde kamuya aktarılacak enformasyonu milyonlarca kişi beklemektedir. $\mathrm{Bu}$ kişiler yaşanılan durum karşısında ekstra bir tedirginlik, korku ve panik yaşayabilmektedirler. Böylesine bir durumda bilgi kaynaklarına ilişkin önem daha fazladır. Bu gibi olağanüstü dönemlerde haberciler, diğer dönemlere oranla daha hassas ve hızlı olmak zorundadır (Koç Akgül, 2017, s. 36). Bu durum "aciliyetin tiranlığı" olarak adlandırılmaktadır. Habercilik üzerindeki zaman baskısı ile doğru, kesin ve yansız haber yapma konusundaki eleştirilerle yüzleșme endișesi, kriz durumlarında gazetecileri daha da gerilimli bir hale sokmaktadır (Örnebring, 2007, s. 76).

Kriz dönemlerinde haberlerin sunuş biçimi kargaşa ve paniğe sebep olacak şekilde değil, haber etiğine uygun biçimde olması gerekir. Bununla beraber haberde kullanılacak görüntülerin dikkatli seçilmesi izleyicilerde meydana gelebilecek olumsuz etkileri kuşkusuz azaltacaktır (Duğan \& Akıncı, 2019, s. 172). Olayın ilk andaki görüntülerini izleyicilere servis ederken seçici olmak ve travmatik etki yaratabilecek görüntüler varsa bunları tekrar tekrar (replay) yayımlamamak kuşkusuz önemlidir. Ayrıca öznel ifadelerden ve ajitasyon dilinden de tereddütsüz bir șekilde uzak durulmalıdır. İnceoğlu'na (2000) göre kriz haberciliğinde duygudan ziyade bilgi içerikli haberlerin yayınlanmasına dikkat edilmelidir. Kriz haberciliği, haberin toplumsal sorumluluğunun en belirgin olduğu süreçlerden birine dair enformasyon sağlamaktadır. Sonuç olarak her zaman için geçerli olduğu gibi kriz dönemlerinde de meslek etiği ve sorumluluklarına bağlı kalarak haberi aktarmak bir habercinin en önemli görevidir (Yüksel, 2010, s. 280). 


\section{Koronavirüs (COVID-19) ve Haber}

Resmi kayıtlara göre ilk olarak 1 Aralık 2019 tarihinde Çin'in Hubei eyaleti Wuhan bölgesinde görülen koronavirüs (COVID-19) vakası, kısa süre içerisinde dünyaya yayılarak pandemiye neden olmuştur. Koronavirüs'ün kaynağı kesin olarak bilinmemekte birlikte zoonotik kökenli olduğunu düşünülmektedir. Söz konusu virüse bağlı yaşanan hastalığın seyri birkaç hafta içinde dünya çapında 100.000 'den fazla vakaya ve binlerce ölüme neden olmuştur (Garfin, Silver \& Holman, 2020, s. 355). Dünya Sağlık Örgütü (WHO), süreçle ilgili olarak 30 Ocak 2020 tarihinde küresel acil durum ilan etmiş ve 11 Mart 2020'de ise koronavirüs salgının bir pandemi olduğunu açıklamıştır (WHO, 2020).

Salgın sürecinin en başından itibaren haber medyası konuyu yakından takip etmekte, koronavirüs sürecinin medyada olan yansıması pek çok araştırmacı tarafından incelenmektedir. $\mathrm{Bu}$ araştırmaların daha çok haberlerin sunum biçimi, ana akım ve alternatif medyaya ilişkin karşılaştırma ve haberlerin kişiler üzerindeki etkisi gibi konular üzerinde yoğunlaşıldığı görülmektedir.

Literatüre bakılacak olursa Olagoke, Olagoke, \& Hughes'in (2020) çalışmasına göre ana akım medyadaki koronavirüs haberlerinin yaygınlaşması ile kişilerdeki depresyon belirtilerinin de artış meydana geldiği ortaya konmuştur. Quandt et al. (2020) ana akım medyanın sosyal medya sayfalarında yayınladıkları koronavirüs haberleri üzerinde yaptıkları içerik analizi sonucunda, ana akım medyadaki haberlerin alternatif medyaya göre daha az komplo teorisi içerdiğini ancak buna karşın ana akım medyada daha fazla sahte haberin servis edildiğini bulgulamışlardır. Stainback, Hearne \& Trieu (2020) ise bu süreçte haber bültenlerinin neredeyse tamamının koronavirüsle geçtiğini ve aşırı bilgi yüklemesinden kaçmanın zor olduğu bir sosyal bağlamın yaratıldığını ileri sürmektedir. Bununla birlikte haber medyasındaki kaynaklar, halk sağlığı uzmanları ve siyasetçilerin birbirleriyle çelişkili mesajları da toplumdaki kafa karışıklığının nedenleri arasındadır. Nielsen, Fletcher, Newman, Brennen and Howard (2020) ise yayınladıkları raporda, 6 farklı ülkeden (Almanya, Amerika Birleşik Devletleri, Arjantin, Birleşik Krallık, Güney Kore ve İspanya) topladıkları verilerden yola çıkarak, insanların koronavirüs hakkındaki haber ve açıklamalara nasıl eriștiklerini ve haber medyasına olan güvenirliğini saptamışlardır. $\mathrm{Bu}$ araştırma sonucunda koronavirüs krizi ile habere olan ilgi daha çok arttığı ve toplumun geleneksel medyaya oranla dijital medyayı daha çok tercih ettiği ortaya çıkmıştır. Yine bu araştırma sonucunda toplumun, koronavirüsle ilgili bilim insanları ve uzman görüşlerine olan güven düzeyi diğer insanların görüşlerine olan güven düzeyinden daha yüksek çıkmıştır. Ancak örneklemdeki ülkelerde de benzerlik göstermesinin yanı sıra özellikle Amerika'da çok ciddi şekilde ortaya çlkan sonuçlardan bir diğeri siyasi polarizasyonun habere olan güveni ciddi boyutta etkilediği üzerinedir. Siyasi olarak hükümet karşıtı olanlar bu süreçte haber medyasına hükümetten daha fazla güvenmiş ve hükümet destekçilerinde ise tam tersi şekilde haber medyasına olan güven düzeyi düşmüştür.

Gemlik, Pektaş ve Arslanoğlu'nun (2021) araştırmasına göre, sağlık haberciliği alanında yayın yapan haber platformları koronavirüs sürecinde daha çok gündem/magazinsel şekilde yayın içeriği oluşturmuşlardır. Seyhan, Zararsız ve Ayaşoğlu'nun (2021) çalışması ise pandemi sürecinin haber medyası aracılığıyla politikleștirildiğini, haber metinlerinin üretimde ardalan ve bağlam bilginin bulunmadığını ve habere konu olan durumun gerçekliğinden ziyade siyasi yapıya destek çıkma ya da muhalefet etme kaygısının temel alındığı bir sürecin yaşandığını öne sürmüştür. 


\section{Yöntem}

Bu kısımda çalışmanın metodolojisi açısından amaç ve önem, araştırma deseni, veri toplama aracı, katılımcıların belirlenmesi, araștırmanın sınırlılıkları, etik kurul izni ve veri analizi gibi başlıklar detaylandırılarak açıklanmıştır.

\section{Amaç ve Önem}

Çalıșmanın temel amacı koronavirüs pandemisi ile gazetecilik mesleğinde değișen ve değişmeyen durumları belirlemeye çalışmaktır. Çalışmanın bir diğer amacı ise koronavirüs pandemisi sürecinde gazetecilerin edindikleri deneyimlerin ortaya çıkartılmasıdır. $\mathrm{Bu}$ kapsamda çalışma için 3 temel araştırma sorusu hazırlanmıştır.

Araștırma Sorusu 1: Koronavirüs pandemisi ile gazetecilik mesleğinde meydana gelen değişimler nelerdir?

Araștırma Sorusu 2: Koronavirüs pandemisi ile gazetecilik mesleğinde değişmeyenler nelerdir?

Araştırma Sorusu 3: Gazeteciler koronavirüs pandemisi sürecinde neler deneyimlemişlerdir?

Yapılan literatür taramasında koronavirüs pandemisinin meslek yaşamına dair etkileri açısından farklı meslek grupları üzerinde fenomenolojik bağlamda çalışmaların yapıldığı görülmüştür. Henüz gazetecilik mesleği üzerine odaklanan böyle bir çalışma mevcut değildir. Bu açıdan bakıldığında konuya ilişkin yerli bir çalışmanın olmaması, çalışmanın önemini arttırmaktadır.

\section{Araştırma Deseni}

Çalışma nitel araştırma yöntemi esas alınarak fenomenolojik (görüngübilim) desen bağlamında inşa edilmiştir. Fenomenolojik desenle kurulan araștırmalarda bireylerin hayatlarına, tecrübelerine ve dünya görüşlerine dair derinlemesine veriler toplanmaktadır. "Burada amaç kişilerin bu deneyimlere istinaden kazandıkları tecrübeleri nasıl algıladıkları, nasıl tarif ettikleri, nasıl yargıladıkları, nasıl hissettikleri ve başkalarına nasıl aktardıklarıdır" (Erdoğan \& Uyan-Semerci, 2021, s. 160) Bu yüzden denilebilir ki fenomenolojinin amacı kişilerin olgulara ilișkin tecrübelerini anlamak ve yorumlamaktır (Van Manen, 2007, s. 12).

\section{Veri Toplama Aracı}

Araştırmada birincil veri toplama tekniklerinden görüşme (mülakat) tekniği kullanılmıştır. Bu tekniğin yapısı ise yarı-yapılandırılmış derinlemesine görüşme ile oluşturulmuştur. Bu veri toplama tekniği "insanların ne düşündüğünü öğrenmek istiyorsan onlara sor" görüşü temel alınarak geliştirilmiştir. Bununla birlikte görüşmelerde ifade edilen görüş ve kavramların fenomenolojisine göre ifade edilen unsurların tamamı doğru ya da yanlış bir şekilde değerlendirilemez. Görüșme sürecinde toplanan veriler, öznenin deneyimi şeklinde değerlendirilir (Geray, 2017, s. 158). Böylece katılımcılara hem daha önce hazırlanan bir form ile sorular yöneltilmiş hem de mülakat sırasında doğan yeni soruların yanıtlanması sağlanmıştır.

\section{Katılımcıların Belirlenmesi}

Patton'a (2018) göre fenomenolojik desen temelinde inşa edilen bir çalışmanın tüm katılımcıları o konuya ya da fenomene ilişkin bir deneyimi yaşamış olmaş gerekir. $\mathrm{Bu}$ görüş temelinde araştırmada katılımcı grubunu oluşturan tüm gazeteciler koronavirüs 
süreci öncesinde aktif olarak gazetecilik yapan ve pandemi ortaya çıktıktan sonra da bu süreci deneyimlemiş ve halen daha gazetecilik yapmaya devam eden kişilerdir.

Çalışma kapsamında görüşme yapılan gazetecilerin gerçek isimleri kullanılmamış, bunun yerine "Gazeteci 1, 2, 3, 4, 5, 6 ve 7" şeklinde kodlanmıştır. Aşağıdaki tabloda çalışma grubunu oluşturan gazetecilere ilişkin bilgiler sunulmuştur.

Tablo 1. Çalışma Grubunu Oluşturan Gazetecilere İliş̧kin Bilgiler

\begin{tabular}{|l|c|c|c|c|}
\hline Katılımcılar & Mesleki Tecrübe Yılı & Eğitim Seviyesi & Cinsiyet & Yaş \\
\hline Gazeteci 1 & 27 & Lisans & Kadın & 47 \\
\hline Gazeteci 2 & 6 & Lisans & Kadın & 29 \\
\hline Gazeteci 3 & 16 & Lisans & Kadın & 38 \\
\hline Gazeteci 4 & 26 & Lisans & Kadın & 44 \\
\hline Gazeteci 5 & 22 & Lisans & Erkek & 50 \\
\hline Gazeteci 6 & 28 & Lisans & Erkek & 29 \\
\hline Gazeteci 7 & 5 & Lisans & Erkek & 50 \\
\hline
\end{tabular}

$\mathrm{Bu}$ araştırmanın çalışma grubu İzmir ilinde yaşayan 7 gazeteci ile oluşturulmuştur. Çalışma grubundan cinsiyet dağılımının yakın olmasını sağlamak için 4 kadın 3 erkek gazeteci ile görüşmeler yapılmıştır. Katılımcıların tamamı lisans mezunudur. Katılıcıların mesleki tecrübeleri ise 5 ile 28 yıl arasında değișkenlik göstermektedir. Katılımcıların yaş dağglımının da 29 ile 50 yaş aralığında olduğu görülmüştür.

\section{Araştırmanın Sınırlııkları}

Araştırmanın birden çok sınırlılığı bulunmaktadır. Öncelikle araştırma sadece gazeteciler üzerinde yürütülen bir araştırmadır. Bu açıdan araştırma evreninin tamamına erişilmesi, zaman ve maliyet açısından olanaksız olduğu için araştırma İzmir ili merkez ilçelerinde görev yapan gazeteciler ile yürütülmüştür. Araştırma veri toplama araçlarından birisi olan derinlemesine görüşme (mülakat) tekniği ile sınırlıdır. Araştırmanın veri toplama aşamasındaki zaman dilimi 10 Mart 2021 - 10 Mayıs 2021 arasıyla sınırlıdır.

\section{Etik Kurul İzni}

Araştırma kapsamında veri toplanabilmesi için Beykent Üniversitesi Sosyal ve Beşeri Bilimler Yayın Etiği Kurulu'na başvurulmuş, 11/03/2021 tarihli ve 971 sayılı yazı ile etik kurul onayı alınmıştır.

\section{Veri Analizi}

Araştırma kapsamında elde edilen veriler betimsel analizle incelenmiștir. Betimsel analiz, toplanan verilerin birleșimden farklı temalar elde edilmesi ve böylece konuya ilişkin elde edilen verilen yorumlanmasını sağlamaktadır. Yıldırım ve Şimşek'e (2013) göre betimsel analiz uygulanırken katılımcıların ifadelerine çoğunlukla yer verilir ve doğrudan alıntıların yapılması tercih edilmektedir. Toplanan veriler sistematik biçimde betimlenir ve yorumlanarak araştırma raporlanır.

\section{Bulgular}

Araștırma sürecinde görüşülen gazetecilerden toplanan verilerin analizi ile birlikte koronavirüs sürecinde gazetecilerin çalışma koşullarında "Değișenler" ve "Değişmeyenler" olarak 2 tema ortaya çıkmıştır. Bu temaların altında ise "kurum içi iletişim, haber kaynağıyla iletişim, sahada haber toplama, sağlık haberi yapma, teknoloji kullanımı, mesai düzeni ve iş güvencesi" şeklinde 7 adet alt tema ortaya çıkmıştır. Bu alt temalar ise gazetecilerin süreçle ilgili görüşleri ve yaşadıkları deneyimler temelinde oluşan kodların 
frekansları alınarak oluşturulmuştur. Araştırmadaki bulgular sonucu ortaya çıkan tema, alt tema ve kodlar aşğıdaki tabloda detaylı şekilde gösterilmiştir.

Tablo 2. Gazetecilerin Koronavirüs Sürecinde Çalıșma Deneyimlerine Illișkin Görüșleri

\begin{tabular}{|c|c|c|c|}
\hline Tema & Alt Tema & Kod & $\mathbf{f}$ \\
\hline \multirow{3}{*}{ Değişenler } & Kurum içi iletişim & $\begin{array}{l}\text { Gündem toplantılarının internet } \\
\text { üzerinden yapılması }\end{array}$ & 5 \\
\hline & Haber kaynağıyla iletişim & $\begin{array}{l}\text { Hasta olması/hastalık belirtisi } \\
\text { Yüz yüze görüşmekten kaçınma } \\
\text { Online görüşmelerin gazeteciyi } \\
\text { tatmin etmemesi }\end{array}$ & $\begin{array}{l}7 \\
5 \\
2\end{array}$ \\
\hline & $\begin{array}{l}\text { Sahada haber toplama } \\
\text { Sağlık haberciliği } \\
\text { Teknoloji kullanımı }\end{array}$ & $\begin{array}{l}\text { Kısıtlı haber içeriği } \\
\text { Daha hızlı haber toplama } \\
\text { Öncelikli } \\
\text { Görüntülü konuşma } \\
\text { uygulamalarına duyulan intiyaç } \\
\text { Haber kaynağının teknoloji kullanımı }\end{array}$ & $\begin{array}{l}6 \\
4 \\
5 \\
6\end{array}$ \\
\hline Değişmeyenler & $\begin{array}{l}\text { Mesai düzeni } \\
\text { İş güvencesi }\end{array}$ & $\begin{array}{l}\text { İş günü sayısında farklılaşma } \\
\text { İş saatlerinde farklılaşma } \\
\text { İşsiz kalma kaygısı }\end{array}$ & $\begin{array}{l}7 \\
7 \\
7\end{array}$ \\
\hline
\end{tabular}

$\mathrm{Bu}$ analitik çerçeveler sayesinde gazetecilerin koronavirüs pandemisi süresince neler yaşadıkları, mesleğin yapış biçimine dair ne gibi etkilerin ortaya çıktığı ve gazetecilik mesleğinin yapılıș biçimde süreçte nelerin değișip değişmediği belirlenmeye çalıșılmıștır.

\section{Kurum İçi İletişim}

Gazetecilere göre pandemi sürecinde yaşanan en belirgin değişikliklerden birisi kurum içi iletişim olmuştur. Bu noktada görüş bildiren katılımcıların büyük bir kısmı, pandemiden önce haber odasında her gün belirlenen saatte yapılan gündem toplantılarının uzun bir süre fiziki olarak yapılmadığını Zoom, Skype, WhatsApp gibi görüntülü konuşma imkânı olanağı sağlayan programlar aracılığıyla bu gündem toplantılarının gerçekleştiğini ifade etmişlerdir. Gazetecilerin bu konuya ilişkin görüşlerinden bazıları aşağıdaki gibidir:

"Süreç internetten ilerledi. Toplantılar Zoom üzerinden yapıldı." (G1)

"Ben Zoom ve Skype gibi uygulamaları çok çok sık kullanan birisi değilim. Pandemiyle birlikte bambaşka bir boyut devreye girdi. Gündem toplantıları online olarak yapılmaya başlandı." (G2) "İtiraf etmek gerekirse Zoom, WhatsApp gibi belli sistemler burada muhteșem bir kurtarıcıydı." (G4)

“WhatsApp gruplarında gündem toplantısı yapılmaya başlandı." (G5)

"Gündem toplantılarımızı yakın temasa engel olmak için yüz yüze yapmadık. Toplantılarımı yine erken saatlerde WhatsApp üzerinden yaptık." (G6) 


\title{
Haber Kaynağıyla İletişim
}

Gazeteciler için koronavirüs sürecinde büyük değişikliğe neden olan ve onları en çok zorlayan unsulardan birisi de haber kaynağı ile iletişimin sınırlanmasıdır. Bu hususta görüş bildiren gazetecilerin tamamı haber kaynağından görüşme için randevu alınmasına rağmen görüşmenin gerçekleşmemesi gibi durumların yaşandığını belirtmişlerdir. Bunun sebebi ise koronavirüs testi pozitif çıkan haber kaynakları ile görüşmeleri zorunlu bir şekilde ertelemek durumunda kaldıklarını belirten gazeteciler ayrıca başka bir rahatsızlığı olsa bile koronavirüs şüphesi taşıyan haber kaynakları için de bu durumun geçerli olduğunu, bu sebeple haber kaynağı ile görüşmelerin ciddi oranda aksadığını belirtmişlerdir. Bu durumla ilgili olarak özellikle Gazeteci 3 ve Gazeteci 7'nin ifadeleri önem arz etmektedir:

\begin{abstract}
"Bire bir, yüz yüze iletişimi biraz zor sağllyoruz. Mesela birisinde randevu allyorum, görüşme zamanımız vs. her şey belli. Ancak daha sonra ufak bir hastalık belirtisi gösterdiyse bile randevumuzu ertelemek zorunda kalıyoruz. Ya da karşı taraf çekinebiliyor, 'yüz yüze görüşmesek telefon ile görüsssek' şeklinde talepleri oluyor." (G3)

"Normal şartlar altında olsak haber kaynağı ile buluşup haber yapacağımız konuları haber yapamadığımız durumlar çok fazla yaşandı." (G7)
\end{abstract}

Bununla birlikte gazetecilere göre koronavirüsün yarattığı tablo haber kaynaklarının pozitif olma ya da hastalık belirtisi göstermelerinin dışında da yüz yüze iletişimi sınırlandırmıştır. Gazetecilerin yanıtlarına göre bazı haber kaynakları yüz yüze değil online görüşmelere izin vermişlerdir:

\footnotetext{
“Gazeteciler olarak rahat değiliz. Bir de karşı taraf da çok yüz yüze röportaj yapmak istemiyor. Virüs nedeniyle insanlar korkuyor." (G1)

"Tele röportajlar çok çoğaldı." (G2)

"Haber kaynakları ile bir araya gelmekte karşı tarafin çok çekinceleri oluyor." (G3)

"Bazı haber kaynakları yüz yüze görüşmek istemedi. Bu süreçte tamamen kişilerle cep telefonu üzerinden ulaştığımız, habercilik yaptığımız, anlık refleksler verdiğimiz bir süreci yaşadık." (G4)

"Bazı haber kaynakları yüz yüze görüşmelerden mümkün olduğunca kaçındı." (G6)
}

Gazeteciler, haber kaynağı ile iletişimin online platformlarda da olsa bir şekilde devam ettiğini belirtirken bazı gazetecilere göre bu koşullar nedeniyle başka bir değişiklik de meydana gelmiştir. $\mathrm{Bu}$ gazetecilere göre online görüşmelerden elde edilen verim, yüz yüze görüşmelerden alınan verimden daha kısıtlıdır.

\begin{abstract}
“Çoğu zaman hem görüntülü hem de fotoğraflı haberler yapıyorum. Görüntülü haberlerde özellikle mikrofonumuzla karșı tarafla iletișim kurmamız gerekiyor. Dolayıslyla bizim için haber kaynağı ile aynı mekânda bulunamamak ciddi bir sorun oldu. Aynı anda aynı mekânda olmamız daha iyi bilgi akışını sağlıyordu." (G3)

“Çoğu kamu kuruluşu online platformlar üzerinden sinırlı bilgiler akıttı. Dolayıslyla onlara mahkum olduk. Onlar bize ne gönderirse onun üzerinden gittik. Onlara mahkûm olduk. Bir basın toplantısı yüz yüze gerçekleştiği zaman konuşmacıya tak diye soru sorabilirdim. Ancak bu gücümü kaybettim. Bu da haberin işleniş modelini, haberin bit tık yukarıya çıkışını engelledi." (G4)
\end{abstract}

\section{Sahada Haber Toplama}

Gazeteciler için bir koronavirüs süreci ile birlikte bir başka değişim de sahada haber toplama aşamasında gerçeklemiştir. Normal zamanlarda güncel haber takibi yaparken yeni insanlarla tanışma firsatı doğurduğunu ve bu durumun yeni haberler yapmak için kapı araladığını belirten katılımcılara göre pandemi ile birlikte bu olanaklar zayıflamıştır. Ayrıca gazeteciler pandeminin birçok sektörü etkilemesinden kaynaklı sahadan haber 
toplama imkânlarının azaldığını belirtmişler ve sokağa çıkma kısıtlamalarının uygulandığı süreçlerde bu durumun daha da arttığını ifade etmişlerdir.

\begin{abstract}
"Sahada olmak çok önemli. İnsanlarla diyalog kuruyorsun, yeni insanlar taniyorsun, yeni olaylar gözlemliyorsun. Ancak pandemi bunu olumsuz etkiledi." (G2)

"Eskiden İzmir'de çok sayıda oda, sivil toplum kurulușu, belediye, yerel yönetimler vb. zaman zaman toplantılara katılırdık. Ayrıca bu olağan toplantıların dışında basını davet ettikleri, projelerle ilgili toplantılar da olurdu. Hem gazeteci meslektaşlarımızla o toplantılarda bir araya gelirdik hem de haber kaynakları ile bire bir iletişime geçme şansımız olurdu. Onlar bize başka haberlerin kapılarını da açardı. Normalde rutin bir toplantıya gitsek bile oradan bașka haberler de çıkarabilirdik. Pandemiyle birlikte bu toplantılar neredeyse hiç yapılamıyor." (G3)

"Sokağa çıkma kısıtlamaları olduğu için ve insanların çoğu bu kısıtlamalara tabii olduğundan dolayı haber yapmakta zorlandığımız durumlar yaşadık." (G7)
\end{abstract}

Gazetecilere göre pandemiyle birlikte sahada haber yapmak için geçirilen süre de kısıtlanmıştır. Gazeteciler hem virüsün bulaş riskini azaltmak hem de haber kaynaklarının çekinceleri yüzünden yüz yüze yapılan haberlerde mümkün olabildiğince hızlı davrandıklarını dile getirmişlerdir.
"Habere gittiğimiz zaman en kısa sürede röportajı yapıyoruz. Bu durum hem virüs kapma tehlikesinden hem de kaynağın çekincelerinden kaynaklanıyor. " (G5)
"Çok titiz olan haber kaynaklarımız vardı. Onların yanından çift maske taktık. Maskesiz fotoğraflanması elzemse bu fotoğraflar uzaktan çekildi. Haber kaynaklarının tedirginliğini azaltmaya çalışacak yaklaşımlar gösterdik." (G6)

\title{
Sağlık Haberciliği
}

Koronavirüs sürecinde gazetecilik mesleğindeki en önemli değişim noktalarından birisi de gazetecilerin ana gündeminin sağlık olmasıdır. Kuşkusuz kriz döneminde kitlelere enformasyonu taşıyan gazeteciler için bu süreç yeni deneyimlerin de kapısını aralamıştır. Katılımcların tamamı bu süreçte sağlık haberlerinin yapılmasına öncelik verdiklerini dile getirmișlerdir. Katılımcılardan Gazeteci 4 ve Gazeteci 7 bu durumu şu șekilde özetlemiştir:

\begin{abstract}
"Sağllk haberciliği alanında çok spesifik bir dönemi yaşadım. COVID-19 ile ilgili haberler yapmak asll en öncelikli hedefimiz haline geldi. Ayrıca eskiden yazdığım bir habere 1 birim hassasiyetle ile yaklaşırken şimdi 3-4 kat daha hassas yaklaşıyorum. Kamu bilgilendirilmesi ve farkındalığı açısından yanlış bir şey söylememek için daha fazla dikkat etmeye çalışıorum." (G4)

"Pandemi gündeme oturduğu için neresinden tutarsanız manşet oluyordu. Biz de sürekli sağllk haberleri yaptık. Sonra pandeminin sağlık dışındaki sektörlere olan etkileri de haber olmaya bașladı." (G7)
\end{abstract}

\section{Teknoloji Kullanımı}

Koronavirüs sürecinde gazeteciler açısından yaşanan bir başka değişiklik ise görüntülü konuşma uygulamalarının haber yapımında sıklıkla kullanılmasıdır. Dijitalleşmenin tüm sektörde yarattığı etki uzun sürerdir gazetecilik alanında da kendisi göstermiş ve internet haberciliği, mobil habercilik, veri haberciliği, drone haberciliği vd. başlıklar etrafında yaşanan dönüşüm literatürde kendine yer edinmişti. Ancak yaşanan kısıtlama süreci sonrasında haber kaynağının görüş ve düşüncelerine yer verilecek haberler açısından Zoom, Skype, WhatsApp vb. görüntülü konuşma uygulamaları kritik bir önem taşımaktadır. Konuyla ilgili olarak gazetecilerin tümü görüntülü konuşma uygulamalarının bu süreçte çok büyük kolaylık sağlandığını ve normale oranla çok daha tercih edildiğini belirtmiştir.

"Bizim direkt insanlarla bire bir görüşmemiz gereken durumlar olduğu için internet teknolojisini eskiye oranla daha fazla kullanmaya başladık." (G3) 
"Online görüşmeler muhteșem bir kurtarıcı mı? Evet, muhteșem bir kurtarıcıydı ama biraz yorucuydu." (G4)

"İnsanlarda bir korku olduğu için kimse röportaj yapmak istemedi. Skype, Zoom gibi programlar aracılı̆̆ıyla röportajlar yapmaya başladık insanlarla." (G7)

Bununla birlikte bazı gazeteciler haber kaynakları ile yapılan çevrimiçi görüşmelerin daha sağlıklı yürütülebilmesi için teknik destek sağladıklarını belirtmişlerdir.

"Geleneksel kuşağın dijital uygulamalara adaptasyonu sırasında sıkıntı yaşamadık dersem yalan olur. Ama yönettik mi? Yönettik. Bu süreçte benim de öğrendiğim şeyler oldu." (G4)

"Haber kaynaklarının çevrimiçi platformlarda fotoğraflanması ve görüntülenmesi açısından sorunlar yaşandık. Açı, ters ışık, çözünürlük ve ses için adeta kısa kısa eğitimler vererek kaynaklarımızdan en verimli görüntü ve bilgileri almaya çalıştık." (G6)

\section{Mesai Düzeni}

Gazetecilerin pandemi öncesi çalışma düzenleri ile pandemi sırasındaki çalışma düzenleri arasında bir farklılık olup olmadığı sorulduğunda verilen yanıtlar birbirine benzer niteliktedir. Gazetecilere göre pandemi öncesi ve pandemi sırasında mesai düzenlerinde ciddi bir farklılık oluşmamıștır. Mesai başında oldukları gün ve saat açısından pandemi öncesine göre neredeyse aynı koşullarda çalıştıklarını ifade etmişlerdir.

"Pandemide mesai düzenimiz değişmedi." (G2)

"Pandemi birçok sektörde çalışma hayatını etkiledi. Bizde de etkileri var ama bizim mesai düzenimizi değiştirmedi." (G3)

"Daha öncesinde de çalışma süreleri olarak ayniydı." (G4)

"Pandemi öncesi ve sonrası çalış̧ma düzenimizde hiç bir şey fark etmedi." (G7)

\section{İş Güvencesi}

Gazeteciler, işsiz kalma kaygısını sürekli olarak yaşadıklarını ifade etmişler, ancak bu durumun medya sektörünün bir gerçeği olduğunu ve konunun pandemiyle bir ilgisinin olmadığını belirtmişlerdir. Ayrıca katılımcılara göre İstanbul'a nazaran İzmir medya sektöründe çalışmak bu tedirginliğin daha çok hissedilmesinde önemli bir rol olmaktadır.

“Bizim sektörümüz merkezi aslında İstanbul. İzmir'in iș imkânları daha kısıtlı kalıyor. Bizim sektörde işsiz kalma tedirginliği her zaman olan bir şeydir. Bir yerden çıkarıldığınızda başka bir yerde iş bulmak zor." (G2)

"Medya sektöründe koşullar çok kısıtll, özellikle İzmir'de. İzmir büyük bir şehir ama maalesef basın-yayıncılık sektör koşullarının çok iyi olduğu bir şehir değil. Bir İstanbul değil.” (G3)

"Türkiye gerçeğinde bugün bu sorunu yaşamayan var mı? Ama bunun pandemi ile hiçbir alakası yok. Sektörün en büyük sorunudur işsizlik." (G4)

"Ben bu sektörde 22 yıldır çalışıyorum ve işsiz kalma kaygısı yaşamadığım bir günüm bile yok." (G5)

\section{Sonuç ve Değerlendirme}

Koronavirüs pandemisi dünya genelinde büyük bir kriz sürecinin yaşanmasına neden olmuştur. Devletler bu sürece hazırlıksız yakalanmış ve başta sağlık olmak üzere pek çok şey kesintiye uğramıș ve insanlık distopik bir manzara ile karşı karşıya kalmıştır. Böylesi bir kriz ortamında birçok iş kolunda yaşanan değişim kuşkusuz haber medyası için de geçerli olmuştur.

Medya içerisinde en önemli faaliyetlerinden birini gerçekleştiren gazetecilerin bu süreçte haber yapmayı nasıl değerlendirdikleri, süreci nasıl yürüttükleri ve hangi durumlarda değişimlerin meydana geldiği gibi deneyimler incelenmeye çalışılmıştır. $\mathrm{Bu}$ amaçla 
meydana gelen değişimlerin gazetecilerdeki yansımalarını anlamak için araştırma koronavirüs süreci özelinde kurgulanmıştır. Çalışma sonucunda koronavirüs sürecinde gazeteciliğin yapılış biçiminde bazı değişimlerin meydana geldiği ortaya çıkmıştır. Gazeteciler için pandemi ile birlikte kurum içi iletişim, haber kaynağıyla iletişim, sahada haber toplama, sağlık haberciliği ve teknoloji kullanımı gibi başlıklarda bir veya daha fazla etkenin bir araya gelmesiyle birlikte değişimlerin yaşandığı görülmektedir.

Araştırma kapsamında ortaya çıkan sonuçlara bakılacak olursa, birçok sektörde olduğu gibi haber medyasında da WhatsApp, Zoom, Skype vb. programlar aracılığıyla iletişim sürecine destek sağlanmıştır. Kurum içinde yüz yüze teması azaltmak adına özellikle gündem toplantıları bu programlar aracılığıyla yapılmıştır. Bu süreçte kurum içi iletişimin bir kısmı online şekilde yürütülmesine rağmen gözle görünür bir oranda dezavantaj yaşanmamıştır. Ancak haber kaynağı ile iletişim için aynı şeyleri söylemenin güç olduğu gözükmektedir. Gazetecilerin pandemi döneminde en çok zorlandıkları değişimlerden birisi haber kaynağı ile iletişim aşamasında yaşanmıştır. Mesleğin büyük oranda kişiler arası iletişim üzerinden yürüyor olması, haber olan şeyin genellikle insan faaliyetleri sonrasında yaşanması ya da herhangi bir olayın insanlar üzerinde bıraktığı etkiyi aktarması nedeniyle gazetecilik açısından zorlayıcı bir süreç yaşanmıştır. $\mathrm{Bu}$ aşamada pandemi dolayısıyla insanların yüz yüze iletişim kurmaktan duydukları çekinceler habercileri online platformlara yönlendirmiş, birçok kez haber kaynakları ile online şekilde görüşmeler yapmışlardır. Ancak bu durum Gazeteci 3 ve Gazeteci 4'ün de belirttiği gibi yapılan haberlerin istenilen ölçüde tatmin etmediği boyutların yaşanmasına neden olmuştur. Ayrıca pandemi ile birlikte sağlık haberciliği öne çıkmış ve gazeteciler bu süreçte sıklıkla sağlık haberleri üretmeye başlamışlardır. Ancak Gazeteci 7'nin ifadesine göre, yapılan haberler ilk etapta sağlık haberciliğine türünde olsa da daha sonra pandeminin başka alanlara etkileriyle ilgili hemen her şeyin haber olması sağlık haberleri dışında da koronavirüsle ilgili çok fazla haber yapılmasına olanak sağlamıștır. Bu durum Madsar ve Yıldırım'ın (2021) çalışmalarında belirttiği gibi basın kuruluşlarının salgınla ilgili daha fazla gündem yaratma isteği ile paralellik göstermektedir.

Koronavirüs sürecinin başında, gazetecilerin sağlık haberciliği bağlamında sıklıkla haberler yaptığı görülürken diğer haber türlerinde ciddi daralmaların yaşandığı gözlemlenmiştir. Gazeteciler, özellikle magazin ve spor haberciliği bağlamında daha kısıtlı içeriklerin üretildiğini ifade etmiștir. Gazeteci 6 bu durumu "Magazin muhabirleri, spor muhabirleri işlerini adeta yapamaz oldular." şeklinde ifade ederken Gazeteci 1 de "Sanatçılar, müzisyenler çalışamıyor. Magazin muhabirleri de çalışamıyor çünkü biz de onlara endeksliyiz." diyerek yaşanan durumu detaylandırmıştır.

Koronavirüs sürecinde gazetecilerin aktif olarak sahada haber toplaması psikolojik olarak daha zorlu bir dönemi de beraberinde getirmiștir. Gazeteci 1 bu konuyla dikkat çekerek durumu şöyle özetlemiştir: "Bu süreç beni fazlasıyla yıprattı. Artık psikolojik bir desteğe ihtiyacım olduğunu düşünüyorum. Çünkü hem virüs kapmamak için mücadele ediyorsun hem de işin gereği virüsün en çok olduğu alanlara giriyorsun. Bu beraberinde büyüyen bir kaygı ve korkuyu getiriyor. Yalnızca benim değil pek çok meslektaşım için durum bu şekilde." Gazeteci 2'de benzer bir görüş bildirmiş ve sürecin daha kaygılı geçtiğini ifade etmiştir: "Hastalığa yakalanma korkusu oluyor insanda ki özellikle bizim girdiğimiz ortamlar kalabalık ortamlar. Insanların yoğun olduğu, sirkülasyonun fazla olduğu ortamlar. Doğal olarak sürekli dışarı çıkmak zorunda olduğumuz için toplu ulaşımı çok daha sık kullanıyoruz. Toplu ulaşım çok büyük risk taşıyor. En çok bu korku yaratıyor." 
Çalışma sonucunda ortaya çıkan bir başka sonuç ise bu süreçte pek çok sektörde mesai düzeninde (esnek çalışma vb.) farklılıklara gidilirken gazeteciler için bu durumu söylemek güçtür. Gazetecilerin pandemi öncesindeki mesai düzeni nasılsa pandemi koşullarında da devam etmiştir. $\mathrm{Bu}$ durum normal dönemde de gazetecilik mesleğinde sinırları belirlenmiş bir mesai kavramı ile çalışılmadığı ile açıklansa da medya sektöründeki daralma, ucuz iş gücü ve güvencesizliğin de bir göstergesi olarak uzun süredir devam eden prekerleșme sürecinin (Çiğdem \& Erdoğan, 2019; Uzunoğlu, 2018) pandemide de devam ettiğinin bir göstergedir. Dünya genelinde pandemi nedeniyle pek çok iş kolunda daralmaya gidilirken gazeteciler açısından bu süreçte iş güvencesi anlamında bir farklılık yaşanmamıştır. Çünkü görüşülen gazetecilerin tamamı, medya sektöründe işsizlik sorunun bir gerçeklik olduğunu ve pandemi sürecinden önce de sürekli olarak bu kaygıyı hissettiklerini söylemiştir. Yine bu durum da medya sektöründeki güvencesizliğin bir başka sonucu olarak değerlendirilebilir.

Koronavirüs pandemisi ile iş yaşamında değişimlerin ortaya çıktığı günümüzde, sürecin gazeteciler açısından nasıl deneyim ve etkiler bıraktığını anlamak için kuşkusuz farklı bölgelerde yürütülen daha kapsamlı araştırmalara ihtiyaç duyulmaktadır. Bununla birlikte özellikle sektörün kalbi sayılabilecek İstanbul'da yapılacak çalışmaların sonuçlarıyla, bu ve diğer bölgelerde yapılan çalışmaların karşılaştırılması kuşkusuz literatüre katkı sağlayacaktır. Bu çalışmada elde edilen tüm bulgular ışığında koronavirüs sürecinde yaşanan değişimlerin gazeteciler için daha zorlu bir çalışma dönemi yarattığı söylenebilir.

\section{Kaynakça}

Çaplı, B. \& O. Taş. (2009). Kriz haberciliği. Çaplı, B. \& Tuncel, H. (Dü) içinde, Televizyon haberciliğinde etik. Ankara: Fersa. 237-250.

Çiğdem, S. \& Erdoğan, E. (2019). Medya endüstrisinde yeni bir prekarizasyon süreci olarak freelance çalışma. Siyaset, Ekonomi ve Yönetim Araştırmaları Dergisi 7(2), 159-69.

Çınarlı, İ. (2016). Kriz iletişimi. İstanbul: Beta.

Duğan, Ö. \& Akıncı. S. (2019). Gazetecilerin kriz dönemlerinde halkla ılişkiler çalışanlarına bakış açılarının belirlenmesine yönelik bir araştırma. Galatasaray Üniversitesi İletişim Fakültesi Dergisi, 30, 167-92.

Durham, F. (2008). Media ritual in catastrophic times: The populist turn in television coverage of hurricane katrina. Journalism, 9(1), 95-116.

Erdoğan, E. \& Uyan-Semerci, P. (2021). Toplumsal araştırma yöntemleri için bir rehber: Gereklilikler, sinırlılık ve incelikler. İstanbul: Bilgi Üniversitesi.

Filiz, E. (2007). Türk Kamu Yönetiminde Kriz Yönetimi. İstanbul: Alfa Aktüel.

Garfin, D. R., Silver, R. C. \& Holman, E. A. (2020). The novel coronavirus (covid-2019) outbreak: Amplification of public health consequences by media exposure. Health Psychology 39(5), 355-57. doi: 10.1037/hea0000875.

Gemlik, N., Pektaş, A. \& Arslanoğlu, A. (2021). Covid-19 salgını sürecinde twitter haberciliği üzerine nitel bir araştırma. J Health Pro Res, 3(1), 15-24.

Geray, H. (2017). Toplumsal araştırmalarda nicel ve nitel yöntemlere giriş. Ankara: Ütopya. 
Güneş, M. \& Beyazıt, E. (2010). Özel işletmelerde kriz yönetimi üzerine genel bir değerlendirme. Aksaray Üniversitesi İktisadi ve İdari Bilimler Fakültesi Dergisi, 2(2), 15-33.

Güngör Firat, D. (2011). Kriz dönemlerinde televizyon yayıncılığı. Radyo ve Televizyon Üst Kurulu (RTÜK). Uzmanlık Tezi, Ankara: RTÜK.

Hatemi, H. (1999). Krizin kritiği. Düşünen Siyaset (Kriz Özel Sayısı), 1(1):1-18.

İnceoğlu, Y. (2000). Uluslararası medya. İstanbul: Beta.

Jarlbro, G. (2004). Krisjournalistik eller journalistik i kris? En forskningso"versikt om medier, risker och kriser. Stockholm: KBM:s Temaserie.

Kalender, A. B. (2019). İnternet haberciliğinde clickbait savaşları: Bir okuyucu tepkisi olarak limon haber örneği. Dördüncü Kuvvet Uluslararası Hakemli Dergi, 2(2):121. doi: 10.33464/dorduncukuvvet.627074.

Koç Akgül, S. (2017). Olağanüstü durumlar, iletişim ve habercilik yaklaşımları. TRT Akademi, 2(3), 6-47.

Kunelius, R. (2020). On the overlap of systemic events: Covid-19, climate, and journalism. Social Media + Society July-Septe:1-4. doi: 10.1177/2056305120948197.

Luengo, M., \& Garcia-Marin, D. (2020). The performance of truth: Politicians, factchecking journalism, and the struggle to tackle COVID-19 misinformation. American Journal of Cultural Sociology, 8, 405-27. doi: 10.1057/s41290-02000115-w.

Lyu, J. C. (2012). How young chinese depend on the media during public health crises? A comparative perspective. Public Relations Review, 38(5), 799-806.

Madsar, S., \& O. Yıldırım. (2021). Covid-19 döneminde habercilik: Haziran 2020'den sonra geçilen yeni normalleşme sonrası salgın ve salgın bağlantılı haberlerin çözümlenmesi. Kritik İletişim Çalışmaları Dergisi, 3(1), 56-81.

Van Manen, M. (2007). Phenomenology of practice. Phenomenology \& Practice, 1(1), $11-$ 30. doi: 10.29173/pandpr19803.

Nielsen, R. K., Fletcher, R., Newman, N., Brennen, J. S. \& Howard, P. N. (2020). Navigating the 'infodemic': how people in six countries access and rate news and information about coronavirus. Misinformation, Science, and Media April 2020.

Nord, L. W. \& Strömbäck, J. (2006). Reporting more, informing less: a comparison of the swedish media coverage of september 11 and the wars in afghanistan and iraq. Journalism, 7(1), 85-110.

Olagoke, A., Olagoke, O. O. \& Hughes, A. M. (2020). Exposure to coronavirus news on mainstream media: the role of risk perceptions and depression. British Journal of Health Psychology, 25(4), 865-74. doi: 10.1111/bjhp.12427.

Olsson, E. K., \& Nord, L. W. (2015). Paving the way for crisis exploitation: The role of journalistic styles and standards. Journalism, 16(3), 341-58.

Örnebring, H. (2007). A necessary profession for he modern age?: Nineteenth centruy news." Butsch, R. \& Macmillan, P. (Ed.), Media and public spheres (s. 71-82) içinde.

Patton, M. Q. (2018). Nitel araştırma ve değerlendirme yöntemleri. (M. Bütün \& S. B. Demir, Çev.) Ankara: Pegem Akademi. 
Quandt, T., Boberg, S. \& Schatto-Eckrodt, T. \& Frischlich, L. (2020). Facebook pages of mainstream news media and the coronavirus crisis - A computational content analysis. Münster Online Research (MOR) Working Paper 2/2020, 1-28.

Riegert, K., \& Olsson, E. K. (2007). The importance of ritual in crisis journalism. Journalism Practice, 1(2), 143-58. doi: 10.1080/17512780701275457.

Seyhan, A. S., Zararsız, Ö. F. \& Ayaşoğlu, E. (2021). Pandeminin politikleştirilmesi ve söylem: Cumhuriyet ve sabah gazeteleri örneğinde koronavirüs haberleri üzerine bir analiz. Akdeniz Üniversitesi İletişim Fakültesi Dergisi, 35, 17-37. doi: 10.31123/ akil.888144.

Spence, P. R., Westerman, D., Skalski, P. D., Seeger, M., Sellnow, T. L. \& Ulmer, R. R. (2006). Gender and age effects on information-seeking after 9/11. Communication Research Reports, 23(3), 217-23.

Stainback, K., Hearne, B. N. \& Trieu, M. M. (2020). COVID-19 and the 24/7 news cycle: Does covid-19 news exposure affect mental health?" Socius: Sociological Research for a Dynamic World 6, 1-15. doi: 10.1177/2378023120969339.

Usher, N. (2009). Recovery from Disaster: how journalists at the new orleans timespicayune understand the role of a post-katrina newspaper. Journalism Practice, 3(2):216-32.

Uzunoğlu, S. (2018). Gazeteci emeğinin dönüşümü ve güvencesizleşme: türkiyeli dijital haber odalarının serbest muhabirleri üzerine bir çalışma. Moment Dergi, 5(2), 195-218.

World Health Organization (WHO). Statement on the second meeting of the international health regulations (2005) emergency committee regard-ing the outbreak of novel coronavirus (2019-ncov) Temmuz 192021 tarihinde https://www.who.int/ news/item/30-01-2020-statement-on-the-second-meeting-of-the-internationalhealth-regulations-(2005)-emergency-committee-regarding-the-outbreak-of-novel-coronavirus-(2019-ncov) adresinden alınd.

Yıldırım, A., \& Şimşek, H. (2013). Sosyal bilimlerde nitel araştırma yöntemleri. İstanbul: Seçkin.

Yüksel, E. (2010). Medya ve habercilik. Konya: Çizgi. 


\title{
Journalism in the Days of Corona: News Tracking in Izmir
}

\author{
A. Buğra Kalender (Lect.) \\ Mete Kazaz (Assoc. Prof. Dr.)
}

\section{Extended Abstract}

News is a mental production that requires serious attention but in times of crisis, more care is needed when reporting. Society, always needs the media to get information and in times of crisis the most important source of information is the media.

Crisis journalism is a subject studied in news research. Especially terrorist attacks and other extraordinary situations are primarily focused on crisis journalism (Lund \& Olsson, 2016, p. 12). Journalists bear a great responsibility towards society, especially in times of crisis. This process includes great difficulties for journalists in terms of satisfying the curiosity of the public, conveying accurate information to people quickly and making people's voices heard.

Pandemic periods are also a serious crisis. However, the resulting effects are not only limited to health but also trigger a multidimensional break, including psychological, sociological and economic. People mostly learn from the media the information they need in order to learn what is going on in this process and to take precautions against the risks they may encounter (Spence, Westerman, Skalski, Seeger, Sellnow \& Ulmer, 2006; Lyu, 2021). The coronavirus pandemic has increased people's search for accurate and reliable information and has once again demonstrated the social and cultural importance of journalism (Luengo \& Garcia-Marin, 2020, p. 406). Journalism deals with national issues, especially in times of crisis, and although the pandemic is large-scale, the current conditions and situation of the country are on the main agenda of broadcasting (Kunelius, 2020, p. 3).

In the literature part of this study, the concept of crisis journalism has been examined and the necessity of journalism has been emphasized. Then, the coronavirus process was looked at as an example of crisis, and the literature on the subject was reviewed by considering the situation of the news media in this process. It has been observed that there are mostly studies on the content of broadcasts in the news media, and the lack of a study on the experiences of journalists in the process has come to the fore.

The main purpose of the study is to try to determine the changing and unchanging situations in the journalism profession with the coronavirus pandemic. Another purpose of the study is to reveal the experiences of journalists during the coronavirus pandemic. In this context, three basic research questions were prepared for the study.

Research Question 1: What are the changed in the journalism profession with the coronavirus pandemic?

Research Question 2: What has not unchanged in the journalism profession with the coronavirus pandemic?

Research Question 3: What have journalists experienced during the coronavirus pandemic?

In the literature review, we saw that phenomenological studies were conducted on different occupational groups in terms of the effects of the coronavirus pandemic on 
professional life. There is no such study focusing on the journalism profession yet. From this point of view, the absence of a domestic study on the subject increases the importance of the study. The study was built in the context of a phenomenological pattern based on the qualitative research method. In researches established with a phenomenological pattern, in-depth data about the lives, experiences and worldviews of individuals are collected. Interview technique, one of the primary data collection techniques, was used in the research. The research was carried out on the data collected in İzmir between 10 March 2021 and 10 May 2021. Data were collected by conducting in-depth interviews with 7 journalists in Izmir. The data obtained within the scope of the research were analyzed with descriptive analysis.

As a result of the analysis of the collected data, 2 themes emerged as "Changed" and "Unchanged" in the working conditions of journalists during the coronavirus process. Under these themes, 7 sub-themes emerged as "internal communication, communication with the news source, news gathering in the field, making health news, use of technology, working order and job assurance". Undoubtedly, there is a need for more comprehensive research conducted with different regions and individuals in order to understand how the process has experienced and affected journalists in today's world where changes have emerged in business life due to the coronavirus pandemic. However, comparing the results of the study to be conducted in different regions will contribute to the literature. However, in the light of all the findings obtained in this study, it can be said that the changes in the coronavirus process have created a more challenging working period for journalists.

Keywords: Communication, Journalism, News, Coronavirus, COVID-19.

Bu makale intihal tespit yazılımlarıyla taranmıştır. İntihal tespit edilmemiştir.

This article has been scanned by plagiarism detection softwares. No plagiarism detected.

Bu çalışmada "Yükseköğretim Kurumları Bilimsel Araştırma ve Yayın Etiği Yönergesi” kapsamında uyulması belirtilen kurallara uyulmuştur.

In this study, the rules stated in the "Higher Education Institutions Scientific Research and Publication Ethics Directive" were followed.

Yazarların çalışmadaki katkı oranları eşittir.

The authors' contribution rates in the study are equal.

Çalışma kapsamında herhangi bir kurum veya kişi ile çıkar çatışması bulunmamaktadır.

There is no conflict of interest with any institution or person within the scope of the study.

\section{Etik Kurul İzni I Ethics Committee Permission}

Bu çalışma, Beykent Üniversitesi Sosyal ve Beşeri Bilimler Yayın Etiği Kurulu tarafından, 11/03/2021 tarihli ve 971 numaralı onay formu ile etik açıdan uygun bulunmuştur.

Within the framework of the decision taken during the meeting by Beykent University Social and Human Sciences Scientific Research and Publication Ethics Committee dated 11/03/2021 and numbered 971; the study does not contain any ethical issues. 